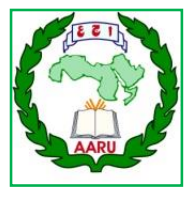

Arab Univ. J. Agric. Sci., Ain Shams Univ., Cairo, Egypt 29(2), 689-700, 2021

Website: http://ajs.journals.ekb.eg

DOI: 10.21608/ajs.2021.77066.1382

\title{
Effect of Different Dried Methods and Storage on Some Enzymes Activity and Quality of Cactus pear and Papaya
}

\section{Marwa M Abdel-Hady ${ }^{*}$, Magdy G El-Shemy ${ }^{2}$, Samar M Mahdy $^{2}$, Effat M Rizk ${ }^{1}$}

1- Food Technology Res Institute, Agric Res Center, Giza, Egypt

2- Food Sciences Dept, Fac of Agri, Ain Shams Univ, P.O. Box 68, Hadayek Shoubra 11241, Cairo, Egypt

* Corresponding author: ma_ma630@yahoo.com

Received 22 May, 2021

Accepted31 August, 2021

\begin{abstract}
This study was to evaluate the activity of peroxidase, polyphenoloxidase, pectin methyl esterase and protease as well as the proximate chemical composition and quality parameters of cactus pear and papaya which were dried by different methods and stored for 6 months. Our findings revealed that the highest moisture content was recorded in osmo - freeze drying of papaya and cactus pear. On the other hand, the browning index of oven dried papaya and cactus pear was higher than those dried with osmotic dehydration and osmo-freeze drying. The less activity of peroxidase was recorded in osmo - freeze drying of papaya and cactus pear. Also, the highest reduction of polyphenoloxidase activity was noticed in osmofreeze drying methods. While oven dried papaya recorded the highest activity of pectin methyl esterase pectin $(0.34 \%)$, complete inactivation was shown in other dried methods after 6 months of storage at $4 \pm 1^{\circ} \mathrm{C}$. Different dried methods of papaya caused to reduce the activity of protease, moreover, complete inactivation was observed after 3 months from storage. The quality parameters for sensory evaluation of dried cactus pear and papaya demonstrated that osmo-freeze drying was
\end{abstract}

more favorable to preserve samples followed by osmotic dehydration and oven drying.

Keywords: Cactus pear, Papaya, Peroxidase, Polyphenoloxidase, Protease

\section{Introduction}

The quality of the dried product by conventional methods, i.e., hot air drying methods are used is the thermal damage to the minerals, and other volatile compounds considered as negative effects on the quality of the final products which can be eliminated by adopting freeze drying (Cholera et al 2016) Quality factors such as colour, flavour and texture in fruits are controlled by enzymes. Meanwhile, any adverse changes on quality either chemical or physical in the fruit are caused by activation of the special enzyme will normally lower quality and/or nutritional value of the fruit (deMan and Lee 2018).

Osmotic dehydration is a method of drying used for partially removed the water from tissue of the plants by immersion in a hypertonic sugar and/or salt solution for reducing the moisture content of foods before actual drying operation. On the other side, osmotic dehydration applied in a wide range for preservation of food materials which caused to lower the water 
activity of fruits and vegetables meanwhile, the osmotic dehydration step may be done before the conventional drying treatment to enhance the mass transfer ratio or decrease the time duration of drying (Shete et al 2018). (Cichowska and Kowalska 2018) reported that the kind of osmotic agent which was used as pre-treatment before drying and storage had significant influence on osmotic dehydration.

Osmotic treatment had been used mainly as pretreatment to some conventional processes such as vacuum drying, freezing and air drying in order to reduce energy costs, improve final quality of products, or even to develop new products (Ramya and Jain 2017) (Ahmed et al 2016) mentioned that, osmotic dehydration caused to improve the nutritional value, functional and sensory properties of final products.

Osmo-freeze drying of sapota slices at 60 Brix osmotic solution concentration, 5 hour immersion time, $50^{\circ} \mathrm{C}$ drying temperature and $-40^{\circ} \mathrm{C}$ freeze drying temperature was found to be the best on the basis of physical, biochemical and sensory properties of osmo-freeze dried sapota( Cholera et al 2016) The use of ternary sucrose salt aqueous solutions had proven to be very effective in water removal from strawberry slices and the beneficial effects of osmotic treatment on freeze dried strawberry sliceshad also been proved (Kumar et al 2020).

Polyphenol oxidase (PPO, EC.1.10.3.1) and peroxidase (POD, EC 1.11.1.7) are related to discolouration (browning) and changes the texture and flavour of the fruits (VamosVigyazo 1981).

Proteases of dried Carica papaya latex are commercially known as crude papain (Poulter and Cay gill 1985). The papain enzyme is a natural proteolytic enzyme which is extracted from the latex in the leaf, the stem and/ or unripe of papaya's fruits (Baeza et al 1989). Carica papaya is a vital plant that is predominant tropical crop in Africa (FAO 2004). It is estimated that global production of papaya will rise by 2.1 percent every year, up to 16.6 million tons in 2029 (FAO 2020).
The papaya fruit is an important of a healthy diet and its pulp is rich in minerals and many vitamins. Papaya has numerous activities such as antibacterial, antiulcer, anti-fertility agent, antioxidant, anticancer activity, antiinflammatory, hepatoprotective, and antidiabetic in addition to the presence of flavonoids, alkaloids and phenolics. (Sharma et al 2020).

The economic and nutritional properties of papaya made it a choice of fruit and/ or vegetable. Also, Papaya is a first rate source of vitamins $\mathrm{A}$ and $\mathrm{C}$ small quantity of thiamine, riboflavin, calcium, iron, potassium, magnesium and sodium (Bari et al 2006).

(Moreno-Castillo et al 2005) reported that, the partial or full drying of cactus pear seems to offer an adequate way dealt with this situation. Osmotic dehydration pre-treatment represents a good choice method to obtain cactus pears of intermediate moisture content which may be consumed and used in food formulations. In addition, the Cactus pear or (prickly pear) is a plant widely grows in arid and semiarid region of the world which considered as a good source of dietary fiber, vitamins and bioactive compounds. Also, it contains natural compounds which have interesting biological activities like hypoglycemic, antimicrobial and anti-inflammatory and a good candidate as antioxidant power. For instance the natural extract of cactus pear used for food, cosmetic applications or pharmaceutics (Silva et al 2021).

Cactus pear (Opuntia ficus indica) is a berry fruits which contains a number of small hard seeds. The pericarp and the edible pulp may have a soft green, greenish, red or purple hues (Stintzing et al 2001). (Valderrama and Clemente 2004) observed that the peroxidase enzyme is involved to a great number of oxidative reactions i.e. colour change, chlorophyll degradation, flavour development, phenol, food quality modification, indole acetic acid oxidation, lignin biosynthesis and pulp softening. Enzymatic browning caused to change light-colour to brown due to the oxidation of phenols to orthoquinones which quickly polymerise to form brown pigments or melanins (Ebiloma et al 2011). 

Activity and Quality of Cactus pear and Papaya

Pectin methyl esterase (PME, EC3.1.1.11) is usually found in the cell-wall of plants which catalyzes the methyl ester bonds, releasing methanol and pectin with free carboxyl groups, PME also catalyzes the de-esterification of pectin and decreasing the degree of methylation (DM). Therefore, the inactivation of endogenous PME in fruits is important to avoid a production of low methoxyl pectins $(\mathrm{DM}<$ $50 \%$ ), which cause reducing of the quality for fruit textures. On the other hand, the low-acid fruits, which contained divalent ions such as calcium, interconnect pairs of carboxyl group different low methoxyl pectin chains, forming aggregation of pectic for instance the substances these phenomena known as cloud loss of fruit juices (Croak and Corredig 2006). Mainly, the inactivation of PME is conducted by using thermal process, which caused a negative impact on the product attributes.

The objective of this study was shed light on the effect of different drying methods on cactus pear and papay a of the activity of peroxidase, polyphenol oxidase, pectin methyl esterase and protease initially after processing and during storage up to 6 months at $4 \pm 1{ }^{\circ} \mathrm{C}$. Also, the quality attributes of dried cactus pear and papaya was also undertaken.

\section{Materials and Methods}

\subsection{Fruit Samples}

Two fruit samples cactus pear (Optuntia ficus indica) with an average weight of 90 to $110 \mathrm{~g}$ having a similar degree of maturity and papaya were obtained from Egyptian local market at season of 2019 in the summer for the first sample and winter for the second sample.

\subsection{Prepared and dried cactus pear and pa- paya with different methods}

The cactus pear was carefully washed with water to eliminate the spines from the peel, and then had peeled with knife while papaya was peeled and cut into slices by knife with approximately equal (into $1 \mathrm{~cm}$ diameter), then both the two fruit samples divided into three parts.
The first part of the prepared fruits (oven dried) was submerged in citric acid solution $\% 1$ for 5 minutes to maintain the colour without changes after that, the samples were taken out of the solution and dried in aerated oven at $50^{\circ} \mathrm{C}$ till obtaining the fixed weight. The second part of fruit was submerged in a $2000 \mathrm{ml}$ beaker contained about $1500 \mathrm{ml}$ of osmotic solution (consists of $1 \%$ citric acid and sugar concentration 50 brix) and divided into two parts the first one which dried by osmotic dehydration immersion for $5 \mathrm{hr}$. at $40^{\circ} \mathrm{C}$ after that the samples were taken out of the solution and dried in oven at $50 \mathrm{c}^{\circ}$ till obtaining the fixed weight. On the other hand, the second which dried by osmo-freeze drying was immersion in the same osmotic solution for $5 \mathrm{hrs}$. then samples were taken out and freezing at $30 c^{\circ}$ for 24 hours after that the freeze osmotic samples were dried in oven. at $50 \mathrm{c}^{\circ}$ till obtaining the fixed weight of the final product of osmo-freeze dried. Cactus pear and papaya all tested samples were done in duplicate.

\subsection{Analytical methods}

\subsubsection{Proximate analysis of dried cactus pear and papaya}

Moisture content, crude fiber, fat, ash and crude protein were determined in fruit samples according to the methods of (AOAC 2015) Total carbohydrates were estimated by difference.

\subsubsection{Measurement of browning index}

The browning index for cactus pear and papaya dried samples defined as its light absorbance at $420 \mathrm{~nm}$. The absorbance of whole papaya and cactus pear dried samples were measured according to (Meydev et al 1977) with slight modification as reported by (Johnson et al 1995). While the samples were centrifuged for $10 \mathrm{~min}$ at $326 \mathrm{xg}$ in a centrifuge, then remove sinking pulp the supernatant was diluted 1:1 with absolute ethanol and allowed to stand $1 \mathrm{hr}$. An additional centrifugation at $326 \mathrm{xg}$ for 10 min completed clarification. Absorbance of the supernatant was measured at $420 \mathrm{~nm}$. 


\subsection{Determination of enzymes activity}

\subsubsection{Polyphenol oxidase activity (PPO)}

Polyphenol oxidase enzyme extracted and assayed according to the method described by (Zenin and park 1978, Galeazzi et al 1981) with some modification as follows:

One hundred $\mathrm{g}$ of both cactus pear and papaya were homogenized in a virtis homogenizer with $250 \mathrm{ml}$ phosphate buffer $0.05 \mathrm{M}, \mathrm{PH}$ 7.0 for $30 \mathrm{~min}$. The homogenate was centrifuged at $12.000 \mathrm{xg}$ for $15 \mathrm{~min}$ and the supernatant was used as a source of the PPO.

Enzyme activity was determined by measuring the increment rate of absorbance at $410 \mathrm{~nm}$ for $2 \mathrm{~min}$ at $25^{\circ} \mathrm{C}$ where the reaction mixture was $2.4 \mathrm{ml}$ of $0.01 \mathrm{M}$ catechol solution $0.5 \mathrm{ml}$ distilled water and $0.1 \mathrm{ml}$ of enzyme solution, while the reference cuvette (blank) was free of the tested enzyme. One unit of enzyme activity was defined as the amount of enzyme which causes a change in absorbance by $0.001 /$ min at $410 \mathrm{~nm}$. (O.D/min).

\subsubsection{Peroxidase (POD) activity of papaya and cactus pear}

The extraction and determination of POD activity was carried out according to (Akyol et al 2006) as follows:

The samples were homogenized in cold $\left(4^{\circ} \mathrm{C}\right)$ sodium phosphate buffer (PH6.5) by blending for $2 \mathrm{~min}$. with 3:7 proportions of sample to the buffer. The slurries were then filtered through cheesecloth to remove solid particles. The supernatants were used as the POD enzyme extracts. The method of (Igual et al 2010) was conducted where the Substrate soiution for assay of POD activity was prepared by mixing $0.5 \mathrm{ml}$ of guaiacol ( $99 \%$ ). $0.5 \mathrm{ml}$ hydrogen peroxide (30\%) and $99 \mathrm{ml}$ sodium phosphate buffer (PH6.5). POD assay was conducted by mixing $0.1 \mathrm{ml}$ of enzyme extract with $3.5 \mathrm{ml}$ substrate solution. Increase in absorbance at $470 \mathrm{~nm}$ was recorded at $25 \mathrm{c}$ with $10 \mathrm{sec}$ intervals for $3 \mathrm{~min}$. the blank was prepared with $0.1 \mathrm{ml}$ water and $3.5 \mathrm{ml}$ substrate solution.
One unit of POD activity was defined as the change in absorbance at $470 \mathrm{~nm} / \mathrm{min}$. (O.D/min) under the assay conditions (Gunes and Bayindirli 1993).

\subsubsection{Pectin methyl esterase (PME) activity of papaya and cactus pear}

The extraction of PME (EC: 3.1.1.11) from papaya and cactus pear carried out as described by (Lee and Macmillan 1968). About $75 \mathrm{~g}$ of samples were homogenized in $130 \mathrm{ml}$ cold $\left(4^{\circ} \mathrm{C}\right), 8.8 \%(\mathrm{w} / \mathrm{v}) \mathrm{NaCl}$ for $15 \mathrm{~min}$. The homogenates were centrifuged at $2000 \mathrm{xg}$ for 10 min. the supernatants were collected, adjust to $\mathrm{PH} 7.5$ with $\mathrm{NaOH}(0.1 \mathrm{~N})$ and were used as enzyme source.

The procedure of (Hagerman and Austin 1986) was applied to measure PME activity as follows: In a cuvette $2.00 \mathrm{ml}$ of pectin solution was mixed with $0.5 \mathrm{ml}$ of bromothymol blue (indicator dye) and about 1.5 of distilled water, and the initial absorbance at $620 \mathrm{~nm}$ (A620) of the mixture was determined v.s. water, the A620 approximately 0.28 was remained constant until the enzyme was added. The reaction was started by adding $0.5 \mathrm{ml}$ enzyme ex tract. Unit activity was calculated as the rate of decreasing in absorbance at $620 \mathrm{~nm}$ per min within 3 min of the reaction at $25^{\circ} \mathrm{C}$.

\subsubsection{Protease activity}

The extraction process of protease from papaya was carried out according to the method reported by (Tsao and Nagayama 1991) as follows:

$50 \mathrm{~g}$ of papaya samples were homogenized with $20 \mathrm{ml}$ of cold $10 \mathrm{mM}$ tris-HCL buffer $\left(5^{\circ} \mathrm{C}\right), \mathrm{PH}$, and centrifuged at $10000 \mathrm{xg}$ for $20 \mathrm{~min}$. The supernatants were filtrated to prepare the crude enzyme. The assay of protease activity with casein as substrate was measured according to the method reported by (Krishhana-Chetanya et al 2000) as follows: A reaction mixture containing $1 \mathrm{ml}$ of enzyme extracts with $1 \mathrm{ml}$ of $1 \%$ casein and $1 \mathrm{ml}$ of $0.02 \mathrm{M}$ phosphate buffer $(\mathrm{PH} 7)$ were incubated at $37^{\circ} \mathrm{C}$ for $3 \mathrm{~h}$. the enzymatic reaction was 

Activity and Quality of Cactus pear and Papaya

stopped by adding $1 \mathrm{ml}$ of $10 \%(\mathrm{w} / \mathrm{v})$ TCA. The precipitated materials were removed by centrifugation at $8000 \mathrm{xg}$ for $10 \mathrm{~min}$. and then the absorbance of cleared supernatants (TCA soluble fractions) was recorded at $570 \mathrm{~nm}$. A control was run in identical manner except that $1 \mathrm{ml}$ of TCA was addedbefore incubation. The unite of Protease activity was expressed as absorbance at $570 \mathrm{~nm}$ per $\min (\mathrm{O} . \mathrm{D} / \mathrm{min})(\mathrm{Ku}-$ nitze 1965).

\subsection{Sensory evaluation}

Dried papaya and dried cactus pear were evaluated for color, taste, flavor, odor and overall acceptability by a taste panel consisting of 12 members at Horticulture Department, the Agriculture research center (Ranganna 2008).

\subsection{Statistical analysis}

Data were analyzed statistically using the analysis variance and the means were further tasted using the least significant difference test (LSD) as outlined by (Steell and Torrie 1980).

\section{Results and Discussion}

\subsection{Proximate chemical composition of dried papaya and cactus pear}

The chemical composition of papaya and cactus pear dried by different methods are presented in Table 1 Results revealed that the percentage of moisture were 85.5 and $84.2 \%$ for papaya and cactus pear. the high moisture content in the fruit pulp of papaya are in agreement with the report of (USDA 2009) that stated that moisture content in papaya fruit ranges from 92-85\% also (Godson et al 2012) mentioned that crude protein content in the papaya fruit pulp ranged from 0.47 to $1.1 \%$ and crude fiber was $0.83 \%$ while, the percentage of moisture were ranged from 9 to 11 and 15 to $16.5 \%$ for oven dried and osmo- freeze drying of papaya and cactus pear respectively. The moisture content was significantly $(\mathrm{p} \leq 0.05)$ lower in oven dried both papaya and cactus pear. However, fresh papaya and cactus pear recorded the highest percentage of moisture recording 84.2 and $86.5 \%$. On the other hand, crud fiber was higher in cactus pear than fresh papaya recording 2.7 and $1.6 \%$ respectively. Also, the content of crude fiber was higher in oven dried both papaya and cactus pears dried by oven than dried by osmotic dehydration and osmofreeze drying. Data also showed that, the total carbohydrates of fresh papaya and cactus pear were 9.3 and $9.2 \%$ and increased by drying recorded 68.55 and $60.15 \%$ for papaya and cactus pear dried by osmo-f reeze drying. Consequently, ash content was higher in fresh cactus pear than papaya and increased as a result of the used drying method.

\subsection{Browning index}

Effect of dehydration process for oven, osmotic and osmo-freeze drying of papaya and cactus pear on the browning index are shown in Table 2. The browning index as (O.D at $420 \mathrm{~nm})$ for fresh cactus pear was higher $(0.230)$ than papaya $(0.115)$. However, the browning increased after drying. The highest browning was noticed for both papaya and/ or cactus pear dried by oven followed by osmotic dehydration and osmo- freeze drying respectively. On the other hand, the browning index was 0.255 and 0.241 for osmotic and osmofreeze drying cactus pear and it was 0.161 and 0.145 for dried papaya. Results also showed that the browning index of papaya and cactus pear dried by osmo-freeze drying was lower than osmotic and oven drying it may be due to use the osmotic solution and freezing before drying. Therefore, the browning index is a good parameter to judge the color of the final dried product. 
Table 1. Proximate chemical composition (\%) of dried papaya and cactus pear (on dry weight basis)

\begin{tabular}{|l|c|c|c|c|c|c|c|c|}
\hline \multirow{2}{*}{ Components } & \multicolumn{4}{|c|}{ Papaya } & \multicolumn{4}{c|}{ Cactus pear } \\
\cline { 2 - 8 } & Fresh & $\begin{array}{c}\text { Oven } \\
\text { drying }\end{array}$ & $\begin{array}{c}\text { Osmotic } \\
\text { dehydration }\end{array}$ & $\begin{array}{c}\text { Osmo- } \\
\text { freeze } \\
\text { drying }\end{array}$ & Fresh & $\begin{array}{c}\text { Osmo- } \\
\text { Oven } \\
\text { drying }\end{array}$ & $\begin{array}{c}\text { Osmotic } \\
\text { dehydration } \\
\text { freeze } \\
\text { drying }\end{array}$ \\
\hline Moisture \% & $86.5^{\mathrm{a}}$ & $9^{\mathrm{c}}$ & $10.98^{\mathrm{b}}$ & $11^{\mathrm{b}}$ & $84.2^{\mathrm{a}}$ & $15^{\mathrm{c}}$ & $16.5^{\mathrm{b}}$ & $16.6^{\mathrm{b}}$ \\
\hline Crude protein \% & $0.95^{\mathrm{d}}$ & $6.78^{\mathrm{a}}$ & $5.99^{\mathrm{b}}$ & $5.12^{\mathrm{c}}$ & $1.03^{\mathrm{c}}$ & $7.5^{\mathrm{a}}$ & $8.4^{\mathrm{b}}$ & $8.3^{\mathrm{b}}$ \\
\hline Fat\% & $0.62^{\mathrm{c}}$ & $1.50^{\mathrm{b}}$ & $1.82^{\mathrm{a}}$ & $1.70^{\mathrm{ab}}$ & $0.91^{\mathrm{c}}$ & $2.59^{\mathrm{a}}$ & $1.37^{\mathrm{b}}$ & $1.27^{\mathrm{b}}$ \\
\hline $\begin{array}{l}\text { Total carbohydrates } \\
\%\end{array}$ & $9.30^{\mathrm{c}}$ & $65.62^{\mathrm{b}}$ & $67.83^{\mathrm{a}}$ & $68.55^{\mathrm{a}}$ & $9.20^{\mathrm{c}}$ & $59.4^{\mathrm{b}}$ & $60^{\mathrm{a}}$ & $60.15^{\mathrm{a}}$ \\
\hline Crude fiber \% & $1.60^{\mathrm{c}}$ & $9.51^{\mathrm{a}}$ & $7.24^{\mathrm{b}}$ & $7.42^{\mathrm{b}}$ & $2.70^{\mathrm{c}}$ & $12.41^{\mathrm{a}}$ & $11.23^{\mathrm{b}}$ & $11.48^{\mathrm{ab}}$ \\
\hline Ash \% & $1.03^{\mathrm{c}}$ & $7.59^{\mathrm{a}}$ & $6.14^{\mathrm{b}}$ & $6.21^{\mathrm{b}}$ & $1.96^{\mathrm{d}}$ & $3.1^{\mathrm{a}}$ & $2.5^{\mathrm{b}}$ & $2.2^{\mathrm{c}}$ \\
\hline
\end{tabular}

Mean with the same letters in the same row in the same fruit are significantly different $(\mathrm{p} \leq 0.05)$

Table 2. Browning index in dried papaya and cactus pear

\begin{tabular}{|l|c|c|}
\hline Treatment & Papaya & Cactus pear \\
\hline control & $0.115^{\mathrm{d}}$ & $0.230^{\mathrm{d}}$ \\
\hline Oven drying & $0.299^{\mathrm{a}}$ & $0.268^{\mathrm{a}}$ \\
\hline Osmotic dehydration & $0.161^{\mathrm{b}}$ & $0.255^{\mathrm{b}}$ \\
\hline Osmo- freeze drying & $0.145^{\mathrm{c}}$ & $0.241^{\mathrm{c}}$ \\
\hline
\end{tabular}

Mean with the same letters in the same column are significantly different $(\mathrm{p} \leq 0.05)$

\subsection{Residual activity of peroxidase (POD)} for papaya and cactus pear dried by different methods during 6 months of storage at $4 \pm 1^{\circ} \mathrm{C}$

Data in Table 3 showed the residual activity of papaya and cactus pear processed by different methods of drying. It could be noticed that the highest residual activity initially in papaya and cactus pear dried by oven after processing followed by osmotic and osmo freeze drying respectively. However, the less residual activity was observed for osmo-freeze drying of papaya and cactus pear, it may bedue to use of osmotic solution and freezing before drying process. Subsequently it could be noticed that a clear reduction in peroxidase activity for papaya and cactus pear dried by different methods by extending the shelf life up to 6 months at $4 \pm 1^{\circ} \mathrm{C}$ and reduction like this was strongly depending on the selecting method of drying and preparation before drying. On the other hand, there was a gradually decrease in the residual activity of peroxidase for different methods of drying cactus pear and papaya by increasing the storage time up to 6 months at $4 \pm 1^{\circ} \mathrm{C}$ where, oven dried papaya recorded the highest residual activity of peroxidase $(0.99 \%)$ followed by osmotic dehydration $(0.46 \%)$ and osmo-freeze drying papaya $(0.40 \%)$. while, the residual activity of peroxidase for cactus pear recorded $2.09 \%, 1.73 \%$ and $0.91 \%$ for cactus pear dried by oven, osmotic dehydration and osmo- freeze drying after 6 months at $4 \pm 1^{\circ} \mathrm{C}$ respectively.

\subsection{Residual activity of polyphenol oxidase (PPO) in cactus pear and papaya dried by different methods during 6 months storage at $4 \pm 1^{\circ} \mathrm{C}$}

The residual activity of polyphenol oxidase (PPO) in cactus pear and papaya with different methods of drying and during 6 months of storage at $4 \pm 1^{\circ} \mathrm{C}$ compared with its activity in fresh cactus pear and papaya are shown in Table 4 data revealed that all methods used for drying of cactus pear and papaya caused to reduce of polyphenol oxidase activity, however, the highest reduction was noticed for osmo-freeze drying of cactus pear and papaya followed by osmotic dehydration and oven drying respectively. The less residual activity of PPO was recorded in osmo- freeze drying cactus pear 
Table 3. Residual activity (\%) of peroxidase in dried papaya and cactus pear du ring 6 months of storage at $4 \pm 1^{\circ} \mathrm{C}$

\begin{tabular}{|l|c|c|c|c|c|c|c|c|c|c|c|c|c|c|}
\hline \multirow{3}{*}{ Treatment } & \multicolumn{10}{|c|}{ Residual activity \% of peroxidase during 6 months of storage } \\
& \multicolumn{10}{|c|}{ Papaya $\mathbf{1} \mathbf{1}^{\circ} \mathbf{C}$ (months) } \\
\cline { 2 - 15 } & $\mathbf{0}$ & $\mathbf{1}$ & $\mathbf{2}$ & $\mathbf{3}$ & $\mathbf{4}$ & $\mathbf{5}$ & $\mathbf{6}$ & $\mathbf{0}$ & $\mathbf{1}$ & $\mathbf{2}$ & $\mathbf{3}$ & $\mathbf{4}$ & $\mathbf{5}$ & $\mathbf{6}$ \\
\hline Control & 100 & & & & & & & 100 & & & & & & \\
\hline Oven drying & 6.67 & 5.32 & 4.93 & 3.29 & 2.17 & 1.58 & 0.99 & 6.45 & 5.81 & 5.18 & 5.00 & 3.91 & 3.00 & 2.09 \\
\hline $\begin{array}{l}\text { Osmotic } \\
\text { dehydration }\end{array}$ & 2.41 & 1.51 & 1.01 & 0.87 & 0.76 & 0.62 & 0.46 & 5.91 & 4.55 & 4.27 & 4.18 & 2.90 & 2.00 & 1.73 \\
\hline $\begin{array}{l}\text { Osmo- freeze } \\
\text { drying }\end{array}$ & 1.32 & 1.01 & 0.89 & 0.81 & 0.56 & 0.49 & 0.40 & 5.45 & 3.91 & 3.64 & 3.55 & 1.81 & 1.27 & 0.91 \\
\hline
\end{tabular}

Table 4. Residual activity (\%) of Polyphenol oxidase in dried papaya and cactus pearduring 6 months of stora ge at $4 \pm 1^{\circ} \mathrm{C}$

\begin{tabular}{|c|c|c|c|c|c|c|c|c|c|c|c|c|c|c|}
\hline \multirow[t]{3}{*}{ Treatment } & \multicolumn{14}{|c|}{$\begin{array}{l}\text { Residual activity \% of polyphenoloxidase during } 6 \text { months of storage } \\
\qquad \text { at } 4 \pm 1^{\circ} \mathrm{C} \text { (months) }\end{array}$} \\
\hline & \multicolumn{7}{|c|}{ papaya } & \multicolumn{7}{|c|}{\begin{tabular}{|c|} 
Cactus pear \\
\end{tabular}} \\
\hline & $\mathbf{0}$ & 1 & 2 & 3 & 4 & 5 & 6 & $\mathbf{0}$ & 1 & 2 & 3 & 4 & 5 & 6 \\
\hline Control & 100 & & & & & & & 100 & & & & & & \\
\hline Oven drying & 3.38 & 2.26 & 1.62 & 1.27 & 1.16 & 0.91 & 0.84 & 4.64 & 3.30 & 0.00 & 0.00 & 0.00 & 0.00 & 0.00 \\
\hline $\begin{array}{l}\text { Osmotic } \\
\text { dehydration }\end{array}$ & 1.72 & 1.25 & 0.92 & 0.75 & 0.66 & 0.54 & 0.44 & 2.69 & 00.0 & 0.00 & 0.00 & 0.00 & 0.00 & 0.00 \\
\hline $\begin{array}{l}\text { Osmo- freeze } \\
\text { drying }\end{array}$ & 1.02 & 0.85 & 0.78 & 0.70 & 0.50 & 0.47 & 0.38 & 2.32 & 0.00 & 0.00 & 0.00 & 0.00 & 0.00 & 0.00 \\
\hline
\end{tabular}

$(2.32 \%)$ and papaya $(1.02 \%)$ after dehydration in this context (Falguera et al 2012) reported that, papaya had a relatively low PPO activity. Also, results indicated that the residual activity of polyphenol oxidase was decreased gradually by increasing the storage period up to 6 months at $4 \pm 1^{\circ} \mathrm{C}$. The residual activity was $3.38,1.72$ and $1.02 \%$ forpapaya dried by oven, osmotic and osmo-freeze drying initially after dehydration respectively. A similar behavior was recorded for cactus pear initially after drying with oven, osmotic and osmo-freeze drying recording 4.64, 2.69 and $2.32 \%$ residual activity of PPO respectively.

On the other hand, the longer of the storage period at $4 \pm 1{ }^{\circ} \mathrm{C}$, the higher the residual of PPO activity was in dried papaya by oven, osmotic and osmo-freeze drying where, the highest value of residual activity of PPO was found in oven dried papaya after 6 months of Storage at $4 \pm 1{ }^{\circ} \mathrm{C}(0.84 \%)$ followed by osmotic $(0.44)$ and osmo- freeze drying $(0.38 \%)$. On the other hand, the residual activity of PPO for oven drying of Cactus pear was 3.3\%after one month of storage at $4 \pm 1^{\circ} \mathrm{C}$ while there was completely inactivation noticed after that and up to 6 months of storage. Also there wasn't any residual activity observed for osmotic and/or osmo -freeze drying cactus pear through storage and up to 6 months therefore, the treatments and the drying methods were more effective for inactivation of polyphenol oxidase (PPO) for dried cactus pear than dried papaya.

\subsection{Pectin methyl esterase (PME) activity in tested papaya dried by different methods during 6 months of storage at $4 \pm 1^{\circ} \mathrm{C}$}

Pectin methyl esterase activity and residual activity in dried papaya by different methods are given in Table 5 generally data concluded that, the pectin methyl estrase in papaya drying by different methods was affected by the selected method of dehydration where, oven 
Table 5. Residualactivity (\%) of pectin methylestera se in dried papaya during 6 months of storage at $4 \pm 1{ }^{\circ} \mathrm{C}$

\begin{tabular}{|l|c|c|c|c|c|c|c|c|}
\hline Treatment & \multirow{2}{*}{$\begin{array}{c}\text { Initial pectin } \\
\text { methylestrease }\end{array}$} & \multicolumn{6}{|c|}{ Residual activity \% of pectin methylestrease during $\mathbf{6}$ months of } \\
& $\begin{array}{l}\text { activity } \\
\text { O.D/min*10-3 }\end{array}$ & $\mathbf{0}$ & $\mathbf{1}$ & $\mathbf{2}$ & $\mathbf{3}$ & $\mathbf{4}$ & $\mathbf{5}$ & $\mathbf{6}$ \\
\hline Control & 54.5 & 100 & & & & & & \\
\hline Oven drying & 0.81 & 1.49 & 1.44 & 1.3 & 1.23 & 0.93 & 0.66 & 0.34 \\
\hline $\begin{array}{l}\text { Osmotic } \\
\text { dehydration }\end{array}$ & 0.73 & 1.34 & 1.14 & 0.88 & 0.69 & 0.51 & 0.31 & 0.00 \\
\hline $\begin{array}{l}\text { Osmo-freeze } \\
\text { drying }\end{array}$ & 0.52 & 0.95 & 0.73 & 0.58 & 0.51 & 0.44 & 0.28 & 0.00 \\
\hline
\end{tabular}

dried papaya recorded higher pectin methyl esterase activity than those dried by osmotic and osmo-freeze drying. The activity of pectin methyl esterase for osmo-freeze drying papaya was 0.52 followed by osmotic dehydration 0.73 and oven drying $0.81 \mathrm{O} . \mathrm{D} / \mathrm{min}^{*} 10^{-3} \mathrm{re}$ spectively, consequentially the residual activity of pectin methyl esterase of dried papaya during 6 months of storage at $4 \pm 1^{\circ} \mathrm{C}$ was affected by the pretreatment used before drying and also the residual activity was declined gradually by extending the shelf life up to 6 months at $4 \pm 1^{\circ} \mathrm{C}$. Meanwhile, osmo-freeze drying papaya had recorded the lowest residual PME $(0.44 \%)$ followed by osmotic dehydration $(0.51 \%)$ and oven drying $(0.93 \%)$ after 4 months of storage at $4 \pm 1^{\circ} \mathrm{C}$ respectively, completely inactivation of PME was observed for both osmotic dehydration and osmo-freeze drying papaya after 6 months of storage at $4 \pm 1^{\circ} \mathrm{C}$ but it remained $(0.34 \%)$ PME in oven drying papaya.

It is important to mention that pretreatment before drying and extending storage period was more effective for inactivation of PME activity. PME participatesin the regulation of $\mathrm{pH}$ of the cell wall by generating protons and thus enhances the hydrolyses activity of the cell wall (Rexova-Benkova and Markovic 1976) also (Lin et al 1991) reported that, PME is considered to be the enzyme of physiological relevance to plant metabolism.

\subsection{Protease activity in tested papaya dried by different methods during storage at $4 \pm 1^{\circ} \mathrm{C}$}

Data in Table 6 showed that the changes of protease activity and residual activity in papaya dried by different methods directly after process and during 6 months of storage at $4 \pm 1^{\circ} \mathrm{C}$. Protease activity of oven drying papaya $\left(0.524 \mathrm{O} . \mathrm{D} / \mathrm{min}^{*} 10^{-3}\right)$ was higher than osmotic $\left(0.448 \mathrm{O} . \mathrm{D} / \mathrm{min}^{*} 10^{-3}\right)$ and osmo-freeze drying of papaya $\left(0.429\right.$ O.D/min* $\left.10^{-3}\right)$. Data also showed that the highest residual activity of protease in oven dried papaya followed by osmotic and osmo-freeze drying papaya respectively, but the residual activity was relatively different owing to the method used for drying of papaya and during 6 months of storage at $4 \pm 1^{\circ} \mathrm{C}$. In addition, the residual activity of protease was reduced by increasing the storage time at $4 \pm 1^{\circ} \mathrm{C}$ up to 2 months for oven drying papaya and up to one month only for both osmotic and osmo-freeze drying papaya, results indicated that there was no residual activity of protease noticed after 2 months of storage at $4 \pm 1^{\circ} \mathrm{C}$ for both osmotic and osmo-freeze drying papaya and at the first of the third month for oven drying papaya, therefore, the pretreatment the type of drying and storage time were affected for inactivation of protease. The residual activity of protease for osmo-freeze drying of papaya was the lowest one followed by osmotic and oven drying of papaya respectively either directly after drying or through storage at $4 \pm 1{ }^{\circ} \mathrm{C}$. 
Activity and Quality of Cactus pear and Papaya

Table 6. Residual activity (\%) of protea se in dried papaya during 6 months of storage at $4 \pm 1{ }^{\circ} \mathrm{C}$

\begin{tabular}{|c|c|c|c|c|c|c|c|c|}
\hline \multirow[t]{2}{*}{ Treatment } & \multirow{2}{*}{$\begin{array}{c}\text { Initial protease } \\
\text { activity } \\
\text { O.D/min*10-3 }\end{array}$} & \multicolumn{7}{|c|}{$\begin{array}{l}\text { Residual activity \% of protease during } 6 \text { months of storage } \\
\qquad \text { at } 4 \pm 1^{\circ} \mathrm{C} \text { (months) }\end{array}$} \\
\hline & & 0 & 1 & 2 & 3 & 4 & 5 & 6 \\
\hline Control & 6 & 100 & & & & & & \\
\hline \begin{tabular}{|l|} 
Oven drying \\
\end{tabular} & 0.524 & 8.73 & 5.00 & 3.88 & 0.00 & 0.00 & 0.00 & 0.00 \\
\hline $\begin{array}{l}\text { Osmotic } \\
\text { dehydration }\end{array}$ & 0.448 & 7.46 & 2.98 & 0.00 & 0.00 & 0.00 & 0.00 & 0.00 \\
\hline $\begin{array}{l}\text { Osmo-freeze } \\
\text { drying }\end{array}$ & 0.429 & 7.15 & 2.33 & 0.00 & 0.00 & 0.00 & 0.00 & 0.00 \\
\hline
\end{tabular}

Table 7. Sensory evaluation of dried papaya and cactus pear

\begin{tabular}{|l|c|c|c|c|c|c|}
\hline \multirow{2}{*}{ Quality attributes } & \multicolumn{3}{|c|}{ Papaya } & \multicolumn{3}{c|}{ Cactus pear } \\
\cline { 2 - 7 } & $\begin{array}{c}\text { Oven } \\
\text { drying }\end{array}$ & $\begin{array}{c}\text { Osmotic } \\
\text { dehydration }\end{array}$ & $\begin{array}{c}\text { Osmo-freeze } \\
\text { drying }\end{array}$ & $\begin{array}{c}\text { Oven } \\
\text { drying }\end{array}$ & $\begin{array}{c}\text { Osmotic } \\
\text { dehydration }\end{array}$ & $\begin{array}{c}\text { Osmo-freeze } \\
\text { drying }\end{array}$ \\
\hline Color & $6.6^{\mathrm{c}}$ & $8.0^{\mathrm{b}}$ & $9.1^{\mathrm{a}}$ & $6.2^{\mathrm{c}}$ & $6.5^{\mathrm{b}}$ & $7.2^{\mathrm{a}}$ \\
\hline Taste & $6.0^{\mathrm{b}}$ & $8.4^{\mathrm{a}}$ & $8.6^{\mathrm{a}}$ & $6.5^{\mathrm{b}}$ & $7.0^{\mathrm{a}}$ & $7.0^{\mathrm{a}}$ \\
\hline aroma & $7.2^{\mathrm{c}}$ & $8.0^{\mathrm{b}}$ & $8.3^{\mathrm{a}}$ & $6.0^{\mathrm{b}}$ & $6.7^{\mathrm{a}}$ & $6.8^{\mathrm{a}}$ \\
\hline texture & $6.2^{\mathrm{b}}$ & $8.5^{\mathrm{a}}$ & $8.4^{\mathrm{a}}$ & $6.3^{\mathrm{b}}$ & $6.8^{\mathrm{a}}$ & $6.7^{\mathrm{a}}$ \\
\hline Overall acceptability & $6.0^{\mathrm{b}}$ & $8.3^{\mathrm{a}}$ & $8.8^{\mathrm{a}}$ & $6.5^{\mathrm{c}}$ & $7.0^{\mathrm{b}}$ & $7.5^{\mathrm{a}}$ \\
\hline
\end{tabular}

Mean with the same letters in the same row the same fruit are significantly different $(\mathrm{p} \leq 0.05)$

Table 8. Sensory evaluation of dried papaya and cactus pearduring 6 months of storage at $4 \pm 1{ }^{\circ} \mathrm{C}$

\begin{tabular}{|c|c|c|c|c|c|c|c|}
\hline \multirow[b]{2}{*}{$\begin{array}{c}\text { Quality } \\
\text { attributes }\end{array}$} & \multirow[b]{2}{*}{$\begin{array}{c}\text { Storage } \\
\text { period }\end{array}$} & \multicolumn{3}{|c|}{ Papaya } & \multicolumn{3}{|c|}{ Cactus pear } \\
\hline & & $\begin{array}{c}\text { Oven } \\
\text { drying }\end{array}$ & $\begin{array}{c}\text { Osmotic } \\
\text { dehydration }\end{array}$ & $\begin{array}{c}\text { Osmo-freeze } \\
\text { drying }\end{array}$ & $\begin{array}{l}\text { Oven } \\
\text { drying }\end{array}$ & $\begin{array}{c}\text { Osmotic } \\
\text { dehydration }\end{array}$ & $\begin{array}{l}\text { Osmo- } \\
\text { freeze dry- } \\
\text { ing }\end{array}$ \\
\hline \multirow[t]{3}{*}{ color } & 0 mon. & $6.6^{\mathrm{a}}$ & $8.0^{\mathrm{a}}$ & $9.1^{\mathrm{a}}$ & $6.2^{\mathrm{a}}$ & $6.5^{\mathrm{a}}$ & $7.2^{\mathrm{a}}$ \\
\hline & 3 mon. & $6.3^{\mathrm{ab}}$ & $7.8^{\mathrm{ab}}$ & $8.9^{\mathrm{ab}}$ & $6.0^{\mathrm{ab}}$ & $6.3^{\mathrm{ab}}$ & $6.9^{\mathrm{ab}}$ \\
\hline & 6 mon. & $6.0^{\mathrm{b}}$ & $7.5^{\mathrm{b}}$ & $8.5^{\mathrm{b}}$ & $5.9^{\mathrm{b}}$ & $6.0^{\mathrm{b}}$ & $6.4^{\mathrm{b}}$ \\
\hline \multirow[t]{3}{*}{ taste } & 0 mon. & $6.0^{\mathrm{a}}$ & $8.4^{\mathrm{a}}$ & $8.6^{\mathrm{a}}$ & $6.5^{\mathrm{a}}$ & $7.0^{\mathrm{a}}$ & $7.0^{\mathrm{a}}$ \\
\hline & 3 mon. & $5.6^{\mathrm{a}}$ & $8.1^{\mathrm{a}}$ & $8.3^{\mathrm{a}}$ & $6.2^{\mathrm{ab}}$ & $6.7^{\mathrm{ab}}$ & $6.6^{\mathrm{ab}}$ \\
\hline & 6 mon. & $5.3^{\mathrm{b}}$ & $7.5^{\mathrm{b}}$ & $7.5^{\mathrm{b}}$ & $5.9^{\mathrm{b}}$ & $6.0^{\mathrm{b}}$ & $6.2^{\mathrm{b}}$ \\
\hline \multirow[t]{3}{*}{ aroma } & 0 mon. & $7.2^{\mathrm{a}}$ & $8.0^{\mathrm{a}}$ & $8.3^{\mathrm{a}}$ & $6.0^{\mathrm{a}}$ & $6.7^{\mathrm{a}}$ & $6.8^{\mathrm{a}}$ \\
\hline & 3 mon. & $7.0^{\mathrm{ab}}$ & $7.8^{\mathrm{a}}$ & $8.1^{\mathrm{a}}$ & $5.8^{\mathrm{ab}}$ & $6.4^{\mathrm{ab}}$ & $7.4^{\mathrm{a}}$ \\
\hline & 6 mon. & $6.6^{\mathrm{b}}$ & $7.5^{\mathrm{b}}$ & $7.6^{\mathrm{b}}$ & $5.6^{\mathrm{b}}$ & $6.0^{\mathrm{b}}$ & $6.1^{\mathrm{b}}$ \\
\hline \multirow[t]{3}{*}{ texture } & 0 mon. & $6.2^{\mathrm{a}}$ & $8.5^{\mathrm{a}}$ & $8.4^{\mathrm{a}}$ & $6.3^{\mathrm{a}}$ & $6.8^{\mathrm{a}}$ & $6.7^{\mathrm{a}}$ \\
\hline & 3 mon. & $5.9^{b}$ & $8.2^{\mathrm{a}}$ & $8.1^{\mathrm{a}}$ & $6.1^{\mathrm{ab}}$ & $6.5^{\mathrm{a}}$ & $6.4^{\mathrm{ab}}$ \\
\hline & 6 mon. & $5.8^{\mathrm{b}}$ & $7.6^{\mathrm{b}}$ & $7.5^{b}$ & $5.7^{\mathrm{b}}$ & $6.0^{\mathrm{b}}$ & $6.0^{\mathrm{b}}$ \\
\hline \multirow{3}{*}{$\begin{array}{l}\text { Overall } \\
\text { acceptability }\end{array}$} & 0 mon. & $6.0^{\mathrm{a}}$ & $8.3^{\mathrm{a}}$ & $8.8^{\mathrm{a}}$ & $6.5^{\mathrm{a}}$ & $7.0^{\mathrm{a}}$ & $7.5^{\mathrm{a}}$ \\
\hline & 3 mon. & $5.7^{\mathrm{ab}}$ & $8.0^{\mathrm{ab}}$ & $8.5^{\mathrm{a}}$ & $6.2^{\mathrm{ab}}$ & $6.7^{\mathrm{ab}}$ & $7.2^{\mathrm{a}}$ \\
\hline & 6 mon. & $5.5^{\mathrm{b}}$ & $7.5^{\mathrm{b}}$ & $7.7^{b}$ & $5.8^{\mathrm{b}}$ & $6.4^{\mathrm{b}}$ & $6.7^{\mathrm{b}}$ \\
\hline
\end{tabular}

Mean with the same letters in the same column the same property are significantly different $(\mathrm{p} \leq 0.05)$ 


\subsection{Quality parameters and sensory evalua- tion of dried papaya and cactus pear}

Results in Table 7 showed that the quality parameters of both cactus pear and papaya dried by different methods after processing. Results indicated that osmo-freeze drying had the best score of color, taste, aroma and overall acceptability after processing directly followed by osmotic dehydration and oven drying respectively.

Sensory characteristics are a vital marker of the potential preferences of consumer. Sensory evaluation of dried papaya and cactus pear stored for 6 months at $4 \pm 1^{\circ} \mathrm{C}$ are given in Table 8 the data indicated that, osmo-freeze drying of both cactus pear and papaya had the highest score of color, taste, aroma and overall acceptability followed by osmotic and oven drying. But osmo-freeze drying osmotic dehydration for papaya and cactus pear had the highest score for texture followed by oven drying respectively. These results are in agreement with (Ahmed et al 2016) they reported that, osmotic dehydration improved the nutritional, functional and organolyptic properties of the product. On the other side, the same pattern parameters for papaya and cactus pear dried with different methods and during storage up to 6 months at $4 \pm 1{ }^{\circ} \mathrm{C}$ were noticed but the scores of these parameters were less than those after drying processing with little significant difference therefore, the osmo-freeze drying of papaya and cactus pear recorded the best sensory parameters on comparing with those dried by osmotic or oven may be due to the osmotic solution and freezing before drying which caused to improve the quality of the dried product.

\section{Conclusion}

Considering the used different methods of drying for cactus pear and papayain relation to enzyme activities of peroxidase, polyphenol oxidase and both pectin methyl esterase and protease in papaya and its quality expressed by organoly ptic parameters during 6 months of storage at $4 \pm 1^{\circ} \mathrm{C}$. Therefore, our results indicated that, osmo-freeze drying cactus pear and papaya had the best quality parameters followed by osmotic dehydration and oven drying of cactus pear and papaya .Also, the selected enzyme in this investigation were correlated well with the quality of dried cactus pear and papaya through storage of the processed samples.

\section{References}

Ahmed I, Qazi IM, Jamal S (2016) Developments in osmotic dehydration technique for the preservation of fruits and vegetables. Innovative Food Science and Emerging Technologies 34, 29-43.

Akyol C, Alpas H, Bayindirli A (2006) Inactivation of peroxidase and lipoxygenase in carrots, green beans, and green peas by combination of high hydrostatic pressure and mild heat treatment. European Food Research and Technology 224, 171-176.

AOAC (2015) Official Method of Analysis. $20^{\text {th }}$ ed. $925.09,923.03,979.09,962.09$ and 4.5.01, Washington, DC, USA.

Baeza G, Correa D, Salas C (1989) Proteolytic enzymes in Carica candamarcensis. Journal of the Science of Food and Agriculture 51, 1-9.

Bari L, Hassan P, Absar N, Haque ME, Khuda MII (2006) Nutritional analysis of two varieties of papaya (Carica papaya) at different maturation stages. Pakistan Journal of Biological Sciences 9, 137-140.

Cholera SP, Patel NC, Gojiya DK (2016) Preparation of sapota powder by osmo-freeze drying. Multilogic in Science 6, 288-296.

Cichowska J, Kowalska H (2018) Effect of osmotic pre-treatment and temperature storage conditions on water activity and colour of dried apple. International journal of Food Engineering 14, 1-7. 
Croak S, Corredig M (2006) The role of pectin in orange juice stabilization: Effect of pectin methylesterase and pectinase activity on the size of cloud particles. Food Hydrocolloids 20, 961-965.

deMan JM, Lee CY (2018) Enzymes. In: deMan, JM, Lee, CY, Finley, JW, Hust, WJ (Eds). Principles of Food Chemistry $4^{\text {th }}$ ed. Van Nostrand Reinhold, New York, USA, pp 397-433.

Ebiloma UG, Arobgba SS, Amini OR (2011) Some activities of peroxidase from mango kernel. International Journal Biological and Chemistry 5, 200-206.

Falguera V, Sánchez-Riaño MA, Quintero-Cerón PJ, Rivera-Barrero AC, Méndez-Arteaga JJ, Ibarz AT (2012) Characterization of polyphenol oxidase activity in juices from 12 underutilized tropical fruits with high agroindustrial potential. Food and Bioprocess Technology 5, 1-7.

FAO (2004) Food and Agriculture Organization United Nations Statistics. http://faostat.fao.org.

FAO (2020) Major tropical fruits - preliminary market results 2019. Rome, Italy, pp 3-4.

Galeazzi MM, Sgarbieri V, Constantides S (1981) Isolation, purification and physicochemical characterization of polyphenol oxidase (PPO) from a dwarf variety of banana (Musa cavendishii, L). Journal of Food Science 46, 150-155.

Godson EN, OjimelukweP, ChinyereE(2012) Chemical composition of leaves, fruit pulp and seeds in some Carica papaya (L) morphotypes. International Journal of Medicinal and Aromatic Plants 2, 200-206.

Gunes B, Bayindirli A (1993) Peroxidase and lipoxygenase inactivation during bleaching of green beans, green peas and carrots. Journal of Food Science and Technology 26, 406-410.

Hagerman A, Austin P (1986) Continuous spectrophotometric assay for plant pectin methyl esterase. Journal of Agricultural and Food Chemistry 34, 440-444.
Igual M, Garcia-Martinez E, Camacho M, Martinez- Navarrete N (2010) Effect of thermal treatment and storage on the stability of organic acids and functional value of grapefruit juice. Food Chemistry 118, 291-299.

Johnson J, Braddock R, Chen C (1995) Kinetics of ascorbic acid loss and non-enzymatic browning in orange juice serum: Experimental rate constants. Journal of Food Science 60, 502-505.

Krishhana-chetanya K, Keshavkant S, Naithani S (2000) Changes in total protein and protease activity in dehydration recalcitrant sal (Shorea robusta) seeds. Silva Fennica 34, 7177.

Kumar V, Kumar P, Kumar A (2020) Optimization of process variables for osmo-freeze drying of strawberry slices using response surface methodology. CIGR Journal 22, 179-189

Kunitze N (1965) Methods of enzymatic analysis $2^{\text {nd }}$ ed. Verlag Academic Press. London, UK, pp 807-814.

Lee M, Macmillan J (1968) Mode of action of pectin enzymes I. Purification and certain properties of tomato pectin esterase. Biochemistry 7, 4005-4010.

Lin TP, Liu CC, Chen SW, Wang WY (1991) Purification and characterization of pectin methyl esterase from ficus awkeotsang makino achenes. Plant Physiology 91, 1445-1453.

Meydev S, Saguy L, Kopelman IJ (1977) Browning determination in citrus products. Journal of Agricultural and Food Chemistry 25, 602-604.

Moreno-Castillo EJ, González-García R, Grajales-Lagunes A, RuizCabrera MA, Abud-Archila M (2005) Water diffusivity and color of cactus pear fruits (Opuntia Ficus Indica) subjected to osmotic dehydration. International Journal of Food Properties 8, 323-336.

Poulter NH, Caygill JC (1985) Production and utilization of papain - a proteolytic enzyme from Carica papaya L. Tropical Science 25, 123-137. 
Ramya V, Jain NK (2017) A Review on osmotic dehydration of fruits and vegetables: an integrated approach. Journal of Food Process Engineering 40, 1-22.

Ranganna S (2008) Hand Book of Analysis and Quality Control for Fruits and Vegetable Products $2^{\text {nd }}$ ed. Tata McGraw Hill Book Co, New Delhi, India, pp 594-625.

Rexova-Benkova L, Markovic O (1976) Pectic enzymes. Advances in Carbohydrate Chemistry and Biochemistery 33, 323-385.

Sharma A, Bachheti A, Sharma P, Bachheti KR, Huse AD (2020) Phytochemistry, pharmacological activities, nanoparticle fabrication, commercial products and waste utilization of Carica papaya L: A comprehensive review. Current Research in Biotechnology 2, 145-160.

Shete YV, Chavan SM, Champawat PS, Jain SK (2018) Reviews on osmotic dehydration of fruits and vegetables. Journal of Pharmacognosy and Phytochemistry 7, 1964-1969.

Silva MA, Albuquerque TG, Pereira P, Ramalho R, VicenteF, Oliveira MB, Costa HS (2021) Review Opuntia ficus-indica L mill: A multi-benefit potential to be exploited. Molecules 26, 951-970.
Steel RG, Torrie JH (1980) Principles and procedures of statistics 2 nd ed. Mc Graw-Hill, New York, USA, p 120.

Stintzing FC, Schieber A, Carle R (2001) Phytochemical and nutritional significance of cactus pear. European FoodResearch Technology 212, 396-407.

Tsao C, Nagayama F (1991) Purification and characterization of proteases from oyster (Crussoirca gigas). Journal Food Biochemistry 15, 81-96.

USDA (2009) United States Department of Agriculture. Agricultural Research serviceNational Nutrient Database for standard reference, release 22, Nutrient data laboratory. http://www.ars.usda.gov./ba/bhnrc/nol

Valderrama P, Clemente E (2004) Isolation and thermostability of peroxidase isoenzymes from apple cultivars Gala and Fuji. Food Chemistry 87, 601-606.

Vamos-Vigyazo L (1981) Polyphenol oxidase and peroxidase in fruits and vegetables. Critical Reviews in Food Science and Nutrition 15, 49-127.

Zenin CT, Park YK (1978) Isoenzymes of polyphenol oxidases from high L-Dopa containing velvet bean. Journal of Food Science 43, 646-647. 